\title{
Pengaruh Sarana Prasarana dan Lingkungan Kerja terhadap Kinerja Guru Di SMP Negeri se-Kecamatan Prabumulih Barat
}

\author{
Marliya ${ }^{\bowtie 1}$, Happy Fitria ${ }^{2}$, Nurkhalis ${ }^{3}$ \\ (1) Sekolah Menengah Pertama Negeri 4 Prabumulih \\ $(2,3)$ Universitas PGRI Palembang
}

$\triangle$ Corresponding author

[rosmawati.gaf@gmail.com]

\begin{abstract}
Abstrak
Penelitian ini bertujuan untuk: 1) mengetahui dan mendeskripsikan pengaruh sarana dan prasarana terhadap kinerja guru; 2) mengetahui dan mendeskripsikan pengaruh lingkungan kerja terhadap kinerja guru; 3) mengetahui dan mendeskripsikan sarana prasarana dan lingkungan kerja terhadap kinerja guru. Jenis penelitian ini adalah penelitian kuantitatif. Hasil penelitian disimpulkan bahwa: 1) sarana prasarana berpengaruh secara signikan terhadap kinerja guru; 2) lingkungan kerja berpengaruh terhadap kinerja guru; 3) sarana prasarana dan lingkungan kerja berpengaruh bersama-sama terhadap kinerja guru.
\end{abstract}

Kata Kunci: Sarana Prasarana; Lingkungan Kerja; Kinerja Guru

\begin{abstract}
This study aims to: 1) identify and describe the effect of facilities and infrastructure on teacher performance; 2 ) knowing and describing the influence of the work environment on teacher performance; 3 ) knowing and describing the infrastructure and work environment on teacher performance. This type of research is quantitative research. The results of the study concluded that: 1) infrastructure has a significant effect on teacher performance; 2) the work environment affects teacher performance; 3 ) infrastructure and work environment jointly influence teacher performance.
\end{abstract}

Keyword: Infrastructure; Work Environment; Teacher Performance

\section{PENDAHULUAN}

Dalam Pembukaan Undang-Undang Dasar 1945 dinyatakan bahwa tujuan dari dibentuknya Negara Kesatuan Republik Indonesia adalah untuk mencerdaskan kehidupan bangsa. Bangsa yang cerdas adalah bangsa yang survive didalam menghadapi berbagai kesulitan. Untuk itu, berbagai elemen yang terlibat dalam kegiatan pendidikan dalam rangka mencerdaskan perlu dikenali sehingga diperlukan pengkajian usaha pendidikan sebagai suatu sistem, yang arahnya untuk mengembangkan potensi individu agar mampu berdiri sendiri, yaitu dengan jalan individu diberi berbagai kemampuan dalam mengembangkan konsep, prinsip, kreativitas, tanggungjawab dan keterampilan, temasuk di dalamnya substansi pendidikan baik pendidik, kurikulum, kepala sekolah, sarana prasarana, peserta didik dan lingkungan pendidikan.

Peningkatan mutu pendidikan ditentukan oleh kesiapan SDM yang terlibat dalam proses pendidikan. Sumber daya manusia dalam suatu organisasi baik formal maupun non formal merupakan unsur yang sangat penting dan dominan dalam melaksanakan kegiatan. Baik atau buruknya kualitas sumber daya manusia tidak dapat dipisahkan dari kualitas pendidikan. Hal ini dikarenakan kualitas pendidikan merupakan faktor penentu dari terciptanya sumber daya manusia yang baik. Kualitas pendidikan itu sendiri dapat tercermin dari pelaksanaan pendidikan yang berjalan, tentu saja tidak terlepas dari peran serta guru yang ada.

Education is the most important indicator of a country's progress (Asvio et al, 2019). Education is a conscious effort to build quality human resources to compete (Tobari et al, 2018). Quality human resources are more important than the wealth of natural resources, because the wealth of natural resources cannot guarantee the welfare and success of a nation (Asvio et al, 2019).

Mulyani (2012) menerangkan bahwa guru merupakan salah satu komponen yang sangat menentukan untuk terselenggaranya proses pendidikan, yaitu sebagai fasilitator dalam proses pembelajaran. Solusi dalam mengatasi permasalahan di atas adalah, dengan mengelola sarana dan prasarana pendidikan agar dapat berkembang secara dinamis (Novita, 2017), sesuai dengan Peraturan Pemerintah No 19 Tahun 2005 tentang Standar Nasional Pendidikan yang menyangkut standar sarana dan prasarana pendidikan secara nasional pada Bab VII Pasal 42. Fasilitas atau sarana dan prasarana pendidikan adalah salah satu dari beberapa sumber 
daya yang penting, serta merupakan gambaran kemajuan suatu lembaga dalam mendukung sepenuhnya kegiatan pembelajaran (Fauzan, 2018: 41).

Guru memegang peranan utama dalam pembangunan pendidikan, khususnya yang diselenggarakan secara formal di sekolah. Guru juga sangat menentukan keberhasilan peserta didik, terutama dalam kaitannya dengan proses pembelajaran. Menurut Djamarah (2010), guru merupakan komponen yang paling berpengaruh terhadap terciptanya proses dan hasil pendidikan yang berkualitas. Oleh karena itu, upaya perbaikan apapun yang dilakukan untuk meningkatkan kualitas pendidikan tidak akan memberikan sumbangan yang signifikan tanpa didukung oleh guru yang profesional dan berkualitas. Dengan kata lain, perbaikan kualitas pendidikan harus berpangkal dari guru dan berujung pada guru pula. Dalam konteks ini guru merupakan faktor kunci. Salah satu indikatornya adalah kebiasaannya untuk belajar dari pengalamannya diri sendiri guna meningkatkan kinerjanya dan kepuasan kerjanya. Untuk mencapai keberhasilan kerja, guru harus memiliki kemampuan dasar untuk melaksanakan tugasnya sebagai tenaga profesional.

Informasi mengenai kinerja guru bagi organisasi sekolah merupakan suatu hal yang penting, karena dapat menunjukkan adanya keberhasilan organisasi sekolah dalam mencapai tujuan. Informasi kinerja guru menunjukkan seberapa jauh hal-hal apa yang telah diperbuat guru dapat memenuhi dan memuaskan masyarakat sebagai pengguna jasa.

Pemerintah telah melakukan berbagai upaya untuk meningkatkan mutu guru. Salah satunya dengan membuat kebijakan tentang sertifikasi guru, baik program sertifikasi melalui jalur portofolio maupun PLPG. Melalui program sertifikasi guru ini diharapkan kinerja guru akan meningkat, sehingga mutu pendidikan akan meningkat pula. Dengan adanya guru yang baik dan berkualitas, dapat meningkatkan kualitas pendidikan. Kualitas suatu pendidikan dapat terlihat dari tingkat profesional guru dalam mengajar. Profesional guru tidak dapat terjadi secara langsung tetapi melalui proses. Dalam menciptakan guru yang profesional, pemerintah telah membuat aturan persyaratan untuk menjadi guru. Dalam Pasal 8 Undang-Undang No. 14 Tahun 2005 tentang Guru dan Dosen menyebutkan bahwa guru wajib memiliki kualifikasi akademik, kompetensi, sertifikat pendidikan, sehat jasmani dan rohani, serta memiliki kemampuan untuk mewujudkan tujuan pendidikan nasional.

Basically, Performance is influenced by two factors, namely individual factors and situation factors. On the individual factor, if someone sees a high performance is a path to meet their needs, then he will follow that path. While the situation factor states that performance is the result of interaction between motivation and basic abilities (Rohma, 2020). If motivation is high but basic ability is low, then performance will be low and if ability is high but motivation is low then performance will be low, or vice versa (Nanang, 2016). In relation to the world of education, teacher's performance can be defined as the extent to which a teacher works to the fullest in accordance with his abilities in an effort to achieve institutional goals (Rohma, 2020).

Selain itu juga, rendahnya kinerja guru di sekolah dipengaruhi oleh berbagai macam faktor diantaranya yaitu kompetensi, motivasi kerja, disiplin kerja, kepuasan kerja, organisasi tempat guru mengajar, kepemimpinan kepala sekolah, maupun adanya kebijakan pemerintah tentang Pendidikan (Abdullah, 2020; Soleh dkk, 2019). Hal ini selaras dengan pendapat Kasmir (2018) yang mengemukakan kinerja guru dipengaruhi oleh beberapa factor diantaranya: lingkungan kerja, budaya organisasi, kepemimpinan, motivasi kerja, disiplin kerja, gaji, kepuasan kerja dan faktor-faktor lainnya. Kinerja guru akan menjadi optimal jika diintegrasikan dengan komponen persekolahan, apakah itu kepala sekolah maupun peserta didik. Dengan demikian, peran guru sangat dominan dalam membentuk peserta didik menjadi manusia yang berkualitas, tanpa mengurangi atau menghilangkan peran dan fungsi yang lain, kinerja guru sebagai pelaksanaan tugas dan kewajiban sebagai pendidik merupakan salah satu faktor yang memegang peranan penting didalam keberhasilan pendidikan (Suharsaputra, 2018; Septiani dan Cahyono, 2019).

Berdasarkan beberapa penjelasan di atas, maka seorang guru dituntut memiliki kinerja yang mampu memberikan dan merealisasikan harapan dan keinginan semua pihak terutama masyarakat yang telah mempercayai sekolah dan guru dalam membina peserta didik. Kinerja guru menjadi tuntutan penting untuk mencapai keberhasilan pendidikan. Dengan kata lain, mutu pendidikan yang baik menjadi tolak ukur bagi keberhasilan kinerja yang ditunjukkan oleh guru. Dimana, salah satu contoh keberhasilan kinerja seorang guru tercermin dari hasil belajar yang diperoleh siswa. Lebih jauh, dari informasi yang ada di sekolah dapat diduga bahwa lingkungan kerja dalam suatu organisasi, maupun sekolah dapat memperlancar pelaksanaan kegiatan pembelajaran. Dengan lancarnya pelaksanaan kegiatan pembelajaran, maka secara tidak langsung kinerja guru akan terlaksana dengan baik. Untuk mengetahui kinerja seorang guru dapat dilakukan dengan pengevaluasian kinerja. Dengan adanya evaluasi, maka guru merasa hasil yang mereka kerjakan dihargai, dapat memacu kinerja para guru.

Penyediaan sarana prasarana kerja dimaksudkan untuk menunjang kegiatan sekolah agar mencapai hasil yang optimal. Hasil yang optimal tersebut merupakan prestasi kerja bagi sekolah termasuk di dalamnya guru yang terlibat. Karena dengan adanya sarana prasarana yang memadai dapat menciptakan hasil yang lebih memuaskan dalam menunjang kegiatan belajar mengajar dan mencapai tujuan yang telah ditetapkan. Husaini 
(2008) menjelaskan bahwa ada beberapa faktor yang dapat meningkatkan kinerja guru antara lain: gaji, sarana dan prasarana, kondisi lingkungan kerja fisik dan kepemimpinan.

Kaitannya dengan penelitian ini adalah dalam pencapaian suatu kerja yang maksimal ada faktor yang mempengaruhinya diantaranya sarana prasarana sekolah. Menurut Barnawi (2012) menjelaskan bahwa Sarana dan prasarana sekolah sangat menunjang pekerjaan guru. Guru yang dilengkapi dengan sarana prasarana yang lengkap dan memadai akan menunjukkan kinerja yang baik daripada guru yang tidak dilengkapi sarana dan prasarana yang memadai. Hal ini menunjukkan bahwa kinerja guru sangat dipengaruhi oleh sarana dan prasarana yang disediakan oleh suatu lembaga pendidikan dan sebaliknya kurang memadainya suatu sarana dan prasarana akan juga mengurangi kinerja mereka. Penyediaan sarana prasarana kerja akan menunjang kegiatan sekolah agar mencapai hasil yang optimal. Hasil yang optimal tersebut merupakan prestasi kerja bagi sekolah termasuk di dalamnya guru yang terlibat. Karena dengan adanya sarana prasarana yang memadai dapat menciptakan hasil yang lebih memuaskan dalam menunjang kegiatan belajar mengajar dan mencapai tujuan yang telah ditetapkan. Sarana adalah semua perangkat peralatan, bahan dan perabot yang secara langsung digunakan dalam proses pendidikan di sekolah. Sedangkan prasarana berarti alat tidak langsung untuk mencapai tujuan. Dalam pendidikan diantaranya; lokasi atau tempat dan bangunan sekolah, sedangkan sarana seperti alat langsung untuk mencapai tujuan pendidikan, diantaranya; ruang, buku, perpustakaan, laboratorium.

Menurut Husaini (2008) selain faktor sarana dan prasarana sekolah, faktor lain yang mempengaruhi kinerja guru adalah lingkungan kerja. Kondisi kerja yang mendukung sangat dibutuhkan yaitu lingkungan kerja yang nyaman untuk mereka. Lingkungan kerja yang baik atau bagus akan memfasilitasi mereka untuk kerja lebih baik pula. Mereka lebih menyukai kondisi fisik yang tidak berbahaya atau nyaman dan sebagian besar dari mereka menyukai tempat kerja yang relatif dekat. Oleh karena itu, lingkungan kerja yang baik turut serta dalam membantu tercapainya tujuan sekolah yang diinginkan sesuai dengan visi dan misi yang ada. Dengan kata lain, semakin kebutuhan guru dalam melaksanakan aktivitas pembelajaran yang dilakukan terpenuhi maka akan semakin tinggi pula keinginan guru tersebut dalam meningkatkan kinerja mereka dalam melakukan tugas dan kewajibannya di sekolah. Hal ini dikarenakan lingkungan kerja yang segar, nyaman, dan memenuhi standar kebutuhan layak akan memberikan kontribusi terhadap kenyamanan guru dalam melakukan tugasnya.

Lingkungan kerja dalam suatu organisasi pendidikan sangat penting untuk diperhatikan. Pencapaian visi dan misi sekolah tidak dapat secara efektif bilamana tidak didukung oleh lingkungan kerja yang menyenangkan. Gaji yang besar, tersedianya alat transfomasi tidak akan berarti apabila guru tidak dapat bekerja dengan nyaman. Nuraini (2013) menjelaskan penciptaan suasana kerja yang baik oleh guru dalam upaya menunjang keberhasilan proses pembelajaran merupakan perwujudan salah satu bentuk dari kode etik profesi keguruan. Oleh sebab itu, guru dan elemen pendukung lainnya harus aktif mengusahakan terciptanya lingkungan kerja yang baik.

Berdasarkan pemaparan di atas dapat disimpulkan bahwa terdapat dua faktor penting yang mempengaruhi kinerja guru dalam pencapaian tujuan pendidikan yaitu pengelolaan sarana prasarana sekolah dan lingkungan kerja guru itu sendiri. Karena pentingnya kedua faktor ini, maka suatu instansi pendidikan seharusnya dapat memfasilitasi guru dengan sarana prasarana yang memadai dan lingkungan kerja yang nyaman bagi para guru.

Berdasarkan hasil observasi peneliti di SMP Negeri Prabumulih pada tanggal 13 Oktober 2019, peneliti menemukan indikator yang menyatakan bahwa sarana prasarana sekolah yang belum memadai dan lingkungan kerja yang belum nyaman bagi para guru. Indikator tersebut antara lain di SMP Negeri Prabumulih terdapat beberapa ruang kelas yang memiliki papan tulis kondisi tidak baik, tidak ada penghapus papan tulis, tidak ada tempat sampah, pintu kelas yang tidak dapat ditutup dan meja guru yang sudah mulai rusak. Peralatan olahraga yang belum lengkap mulai dari matras dalam kondisi tidak baik, beberapa bola voli dan bola kaki yang sudah tidak dapat digunakan. Dalam laboratorium IPA yaitu terdapat beberapa alat yang digunakan dalam pembelajaran mulai rusak diantaranya mikroskop dan ada beberapa alat termometer yang masih belum ada. Dalam laboratorium komputer terdapat beberapa unit komputer yang tidak dapat digunakan, dan akses internet yang masih sulit, hal ini menghambat pembelajaran komputer di SMP Negeri Prabumulih. Serta peneliti menemukan atau melihat lingkungan kerja yang belum nyaman bagi guru yang mengajar disana, diantaranya lingkungan ruang guru yang tidak tertata rapi serta ruang kelas yang kotor, kurangnya pencahayaan yang cukup di dalam kelas dan terdapat berbagai hal yang mengganggu pada saat pembelajaran berlangsung diantaranya sering kali adanya peserta didik atau guru lewat di depan kelas tersebut sehingga konsentrasi belajar pun sering terganggu dan suara bising dari luar kelas yang terdengar sampai ke dalam kelas. karena ada beberapa unit pintu kelas yang tidak dapat ditutup rapat. Hal ini mengakibatkan terciptanya pembelajaran yang kurang kondusif. Oleh sebab itu, dari observasi awal peneliti dan wawancara yang dilakukan kepada para guru, karena berbagai kendala yang telah disebutkan dari sarana prasarana sekolah dan lingkungan kerja yang belum nyaman mengakibatkan terdapat beberapa kompetensi guru yang tidak 
tercapai secara maksimal dalam pembelajaran dan hal tersebut mempengaruhi keberhasilan kegiatan belajar mengajar pada peserta didik.

\section{METODE PENELITIAN}

Menurut Sugiyono (2016) metode penelitian pada dasarnya merupakan cara ilmiah untuk mendapatkan data dengan tujuan dan kegunaan tertentu. Berdasarkan hal tersebut terdapat empat kata kunci yang perlu diperhatikan yaitu cara ilmiah, data, tujuan dan kegunaan. Jenis penelitian ini adalah penelitian kuantitatif. Menurut Musfiqon (2012) penelitian kualitatif adalah penelitian yang difokuskan pada kajian fenomena objektif untuk dikaji secara kuantitatif. Penelitian ini merupakan penelitian survey dengan pendekatan kuantitatif. Penelitian kuantitatif adalah penelitian yang digunakan untuk menjawab permasalahan melalui Teknik pengukuran yang cermat terhadap variabel-variabel tertentu, sehingga menghasilkan simpulan-simpulan yang dapat digeneralisasikan, lepas dari konteks waktu dan situasi serta jenis data yang dikumpulkan terutama data kuantitatif (Arifin, 2012).

Subyek penelitian adalah guru sedangkan obyek penelitian adalah sarana prasara. Populasi dalam penelitian yaitu kepala sekolah dan seluruh guru di SMP Negeri Sekecamatan Prabumulih Barat. Sampel dalam penelitian diambil guru-guru yang sudah memiliki pengalaman mangajar di atas satu tahun dan berpendidikan S1. Penelitian survey dimaksudkan untuk memperoleh gambaran umum mengenai pengaruh sarana prasarana dan lingkungan kerja terhadap kinerja guru di SMP Negeri se-Kecamatan Prabumulih Barat.

\section{HASIL DAN PEMBAHASAN}

\section{Pengujian Hipotesis Variabel Sarana Prasarana (X1) terhadap Kinerja Guru (Y)}

Pengaruh Sarana Prasarana (X1) terhadap Kinerja Guru (Y) di SMP Negeri se-Kecamatan Prabumulih Barat. Adapun hipotesisnya adalah sebagai berikut: Ha1: Terdapat pengaruh yang signifikan sarana prasarana terhadap kinerja guru di SMP Negeri se-Kecamatan Prabumulih Barat. Ho1: Tidak terdapat pengaruh sarana prasarana terhadap kinerja guru di SMP Negeri se-Kecamatan Prabumulih Barat.

Model hubungan disiplin terhadap kinerja guru dinyatakan dalam bentuk persamaan regresi $Y=$ $96,854+0,482 \times 1$. Uji signifikansi persamaan regresi dapat disajikan pada tabel 1.

Tabel 1.

Uji Hipotesis Pengaruh Sarana Prasarana terhadap Kinerja Guru di SMP Negeri se-Kecamatan Prabumulih Barat

\section{Coefficients $^{\mathrm{a}}$}

\begin{tabular}{|c|c|c|c|c|c|}
\hline \multirow[b]{2}{*}{ Model } & \multicolumn{2}{|c|}{$\begin{array}{c}\text { Unstandardized } \\
\text { Coefficients }\end{array}$} & \multirow{2}{*}{$\begin{array}{c}\text { Standardized } \\
\text { Coefficients } \\
\text { Beta }\end{array}$} & \multirow[b]{2}{*}{$\mathrm{T}$} & \multirow[b]{2}{*}{ Sig. } \\
\hline & $\mathrm{B}$ & Std. Error & & & \\
\hline 1 (Constant) & 96,854 & 13,097 & & 7,395 &, 000 \\
\hline Sarana Prasarana &, 482 & ,148 & ,376 & 6,552 & ,000 \\
\hline
\end{tabular}

a. Dependent Variable: Kinerja Guru

Berdasarkan uji regresi sederhana di atas, kinerja guru dipengaruhi positif oleh kompetensi profesional guru dengan nilai koefisien 0,482. Atau dengan kata lainnya, kinerja guru akan meningkat apabila didukung dengan kepemimpinan kepala sekolah yang baik. Selain itu, diperoleh pula nilai probabilitas $(0,000)$ lebih kecil dari nilai $f t(0,05)$, selain itu, untuk nilai thitung sebesar 6,552 dengan $t(0,05)(1,297)$ Dengan demikian nilai thitung $(6,552)$ lebih besar dari nilai ttabel $(1,297)$ sehingga dapat disimpulkan bahwa $\mathrm{Ha}$ diterima. Artinya, terdapat pengaruh yang signifikan sarana prasarana terhadap kinerja guru di SMP Negeri se-Kecamatan Prabumulih Barat.

\section{Pengujian Hipotesis Lingkungan Kerja (X2) terhadap Variabel Kinerja Guru (Y)}

Pengaruh lingkungan kerja terhadap kinerja guru. Hipotesisnya adalah sebagai berikut. Ha2: Terdapat pengaruh yang signifikan antara lingkungan kerja terhadap kinerja guru di SMP Negeri se-Kecamatan Prabumulih Barat. Ho2: Tidak terdapat pengaruh yang signifikan antara lingkungan kerja terhadap kinerja guru di SMP Negeri se-Kecamatan Prabumulih Barat.

Model hubungan lingkungan kerja terhadap kinerja guru dinyatakan dalam bentuk persamaan regresi $Y=107,136+0,592 \times 2$. Uji signifikansi persamaan regresi dapat disajikan pada tabel 2.

Berdasarkan uji signifikansi, kinerja guru dipengaruhi positif oleh lingkungan kerja dengan nilai koefisien 0,592. Dengan ini, kinerja guru akan meningkat apabila didukung dengan motivasi kerja yang baik. Selain itu, diperoleh pula nilai probabilitas $(0,000)$ lebih kecil dari nilai $f \mathrm{t}(0,05)$, selain itu, untuk nilai thitung sebesar 2,313 dengan $t(0,05)(1,297)$. Dengan demikian nilai thitung $(2,313)$ lebih besar dari nilai t tabel $(1,297)$ sehingga dapat disimpulkan bahwa Ha diterima. Artinya, terdapat pengaruh yang signifikan lingkungan kerja terhadap kinerja guru di SMP Negeri se-Kecamatan Prabumulih Barat. 
Tabel 2. Uji hipotesis pengaruh lingkungan kerja terhadap kinerja guru

Coefficients $^{a}$

\begin{tabular}{|cc|c|c|c|c|c|}
\hline & \multicolumn{2}{|c|}{$\begin{array}{c}\text { Unstandardized } \\
\text { Coefficients }\end{array}$} & $\begin{array}{c}\text { Standardized } \\
\text { Coefficients }\end{array}$ & & \\
\cline { 2 - 4 } & Model & $\mathrm{B}$ & Std. Error & Beta & $\mathrm{T}$ & Sig. \\
\hline 1 & (Constant) & $\begin{array}{c}107,13 \\
6\end{array}$ & 13,339 & & 8,032 &, 000 \\
& $\begin{array}{c}\text { Lingkungan } \\
\text { Kerja }\end{array}$ &, 592 &, 146 &, 179 & 2,313 &, 000 \\
\hline
\end{tabular}

a. Dependent Variable: Kinerja Guru

\section{Pengujian Hipotesis Simultan Variabel X1 dan X2 ke Y}

Berdasarkan Tabel 3 (coefficients) adalah sebagai berikut: $Y=111,234+0,455 X 1+0,684 X 2$. Dari persamaan tersebut dapat diuraikan sebagai berikut: 1). Nilai konstanta 111,234 yang berarti jika tidak ada variabel sarana prasarana dan lingkungan kerja, maka nilai kinerja guru sebesar 111,234. 2). Nilai koefisien variabel sarana prasarana sebesar 0,455. Artinya, jika sarana prasarana meningkat sebesar 1 (satu) unit maka kinerja guru akan bertambah sebesar 0,455 dengan asumsi variabel lingkungan kerja nilainya 0 . 3). Nilai koefisien variabel lingkungan kerja sebesar 0,684. Artinya, jika lingkungan kerja meningkat sebesar 1 (satu) unit maka kinerja guru akan bertambah sebesar 0,684 dengan asumsi variabel sarana prasarana dan nilainya 0 . Artinya, sarana prasarana dan lingkungan kerja merupakan faktor penting dalam meningkatkan kinerja guru di sekolah. Untuk melihat pengaruh variabel bebas terhadap variabel terikat dengan menggunakan uji $F$ yang dapat dilihat pada Tabel 4.

Tabel 3. Uji Regresi Berganda Coefficients ${ }^{a}$ Coefficients $^{\mathrm{a}}$

\begin{tabular}{|c|c|c|c|c|c|}
\hline \multirow[b]{2}{*}{ Model } & \multicolumn{2}{|c|}{$\begin{array}{l}\text { Unstandardized } \\
\text { Coefficients }\end{array}$} & \multirow{2}{*}{$\begin{array}{c}\begin{array}{c}\text { Standardized } \\
\text { Coefficients }\end{array} \\
\text { Beta }\end{array}$} & \multirow[b]{2}{*}{$\mathrm{T}$} & \multirow[b]{2}{*}{ Sig. } \\
\hline & $\mathrm{B}$ & Std. Error & & & \\
\hline 1 (Constant) & $\begin{array}{r}111,23 \\
4\end{array}$ & 17,483 & & 6,362 & ,000 \\
\hline $\begin{array}{l}\text { Sarana } \\
\text { Prasarana }\end{array}$ & , 455 & , 149 & ,051 & 4,367 & ,000 \\
\hline $\begin{array}{l}\text { Lingkungan } \\
\text { Kerja }\end{array}$ & ,684 & , 149 & ,172 & 3,234 & ,000 \\
\hline
\end{tabular}

a. Dependent Variable: Kinerja Guru

\begin{tabular}{|c|c|c|c|c|c|c|}
\hline \multicolumn{7}{|c|}{$\begin{array}{l}\text { Tabel 4. Uji Simultan (F) } \\
\text { ANOVA }^{\mathrm{a}}\end{array}$} \\
\hline & & Sum of Squares & Df & Mean Square & $\mathrm{F}$ & Sig. \\
\hline \multirow[t]{3}{*}{1} & Regression & 14,568 & 2 & 7,284 & 5,915 &, $000^{b}$ \\
\hline & Residual & 406,024 & 51 & 7,961 & & \\
\hline & Total & 420,593 & 53 & & & \\
\hline
\end{tabular}

a. Dependent Variable: Kinerja Guru

b. Predictors: (Constant), Lingkungan Kerja, Sarana Prasarana

Berdasarkan f hitung pada Tabel 4 di atas diketahui 5,915, sedangkan Ftabel diperoleh sebesar 3,17 dimana fhitung > ftabel yang berarti Ha diterima atau dengan kata lain ada pengaruh yang signifikan sarana prasarana dan lingkungan kerja secara bersama-sama terhadap kinerja guru. Untuk mengetahui besarnya pengaruh sarana prasarana dan lingkungan kerja bersama-sama terhadap kinerja guru dapat dilihat pada Tabel 5.

Berdasarkan hasil perhitungan koefisien diterminasi pada Tabel 5 dapat diketahui bahwa besar pengaruh sarana prasarana dan lingkungan kerja secara bersama-sama terhadap kinerja guru di SMP Negeri se-Kecamatan Prabumulih Barat, sebesar 53,5\% sisanya 46,5\% dipengaruhi oleh faktor lainnya yang tidak termasuk dalam variabel variabel pada penelitian ini. 
Tabel 5. Koefisien Determinan

Model Summary

\begin{tabular}{|l|c|r|r|r|}
\hline Model & R & R Square & $\begin{array}{c}\text { Adjusted R } \\
\text { Square }\end{array}$ & $\begin{array}{c}\text { Std. Error of } \\
\text { the Estimate }\end{array}$ \\
\hline 1 &, $186^{\mathrm{a}}$ &, 535 &, 683 & 2,822 \\
\hline
\end{tabular}

a. Predictors: (Constant), Lingkungan Kerja, Sarana Prasarana

Barnawi (2012) Sarana adalah semua perangkat peralatan, bahan dan perabot yang secara langsung digunakan dalam proses pendidikan di sekolah. Sedangkan prasarana berarti alat tidak langsung untuk mencapai tujuan. Dalam pendidikan diantaranya; lokasi atau tempat dan bangunan sekolah, sedangkan sarana seperti alat langsung untuk mencapai tujuan pendidikan, diantaranya; ruang, buku, perpustakaan, laboratorium. Adapun yang dimaksud prasarana pendidikan atau pengajaran dalam proses pembelajaran, seperti, halaman sekolah, kebun sekolah, taman sekolah, dan jalan menuju sekolah. Sarana prasarana sekolah sendiri menjadi sesuatu hal yang sangat penting bagi guru karena dengan adanya fasilitas yang lengkap bagi mereka ini akan dapat memudahkan para guru dalam berkerja sehingga kinerja guru akan semakin meningkatkan jika sarana prasarana pedukung mereka dalam berkerja bisa terpenuhi. Melalui penelitian ini dapat diketahui bahwa sarana prasarana memberikan pengaruh yang cukup besar terhadap kinerja guru di SMP Negeri se-Kecamatan Prabumulih Barat.

Menurut Nuraini (2013) penciptaan suasana kerja yang baik oleh guru dalam upaya menunjang keberhasilan proses pembelajaran merupakan perwujudan salah satu bentuk dari kode etik profesi keguruan. Oleh sebab itu, guru dan elemen pendukung lainnya harus aktif mengusahakan terciptanya lingkungan kerja yang baik, namun lingkungan kerja mempunyai pengaruh langsung terhadap para guru yang melaksanakan proses belajar mengajar tersebut. Berdasarkan uraian di atas, maka dapat disimpulkan bahwa semakin nyaman lingkungan kerja, maka semakin baik kinerja guru di SMP Negeri se-Kecamatan Prabumulih Barat, dan sebaliknya semakin buruknya lingkungan kerja, maka semakin kurang baik kinerja guru di SMP Negeri seKecamatan Prabumulih Barat.

\section{SIMPULAN}

Berdasarkan penjelasan di atas bahwa ada banyak faktor yang mempengaruhi kinerja guru diantaranya sarana prasarana dan lingkungan kerja. Dimana hasil penelitian ini juga menunjukkan bahwa 1). Ada pengaruh sarana prasarana terhadap kinerja guru di SMP Negeri se-Kecamatan Prabumulih Barat. Besarnya pengaruh sarana prasarana terhadap kinerja guru di SMP Negeri se-Kecamatan Prabumulih Barat sebesar $32,6 \%$ sisanya $67,4 \%$ dipengaruhi oleh faktor lain yang bukan menjadi variabel dalam penelitian ini. 2). Ada pengaruh lingkungan kerja terhadap kinerja guru di SMP Negeri se-Kecamatan Prabumulih Barat. Besarnya pengaruh lingkungan kerja terhadap kinerja guru di SMP Negeri se-Kecamatan Prabumulih Barat sebesar $43,2 \%$ dan sisanya $56,8 \%$ dipengaruhi oleh faktor lain yang bukan menjadi variabel dalam penelitian ini. 3). Ada pengaruh sarana prasarana dan lingkungan kerja secara bersama-sama terhadap kinerja guru di SMP Negeri se-Kecamatan Prabumulih Barat. Besar pengaruh sarana prasarana dan lingkungan kerja secara bersama-sama terhadap kinerja guru di SMP Negeri se-Kecamatan Prabumulih Barat, sebesar 53,5\% dan sisanya $46,5 \%$ dipengaruhi oleh faktor lainnya yang tidak termasuk variabel-variabel pada penelitian ini.

\section{UCAPAN TERIMA KASIH}

Penulis mengucapkan terima kasih diberikan kepada kepala sekolah dan guru SMP Negeri se Kecamatan Prabumulih dan semua pihak yang membantu penulisan dan penerbitan jurnal ini sehingga artikel ini dapat dipublikasikan.

\section{DAFTAR PUSTAKA}

Abdullah, A. (2020). Relationship the Work Culture and Training Programs Within Performance. International Journal of Progressive Sciences and Technologies (IJPSAT), 20(1).

Asvio, N., Yamin, M., \& Risnita. (2019). Influence of Leadership Style, Emotional Intelligence and Job Satisfaction toward Organizational Commitment (Survey at SMA Muhammadiyah South Sumatera). International Journal of Scientific \& Technology Research 8 (8).

Barnawi. (2012). Manajemen Sarana dan Prasarana Sekolah. Yogyakarta: Ar Ruzz Media

Djamarah. (2010). Guru dan Anak Didik. Jakarta: Rineka Cipta

Fauzan. (2018). Pengaruh Relijiusitas Terhadap Prestasi Kerja Pegawai Alumni dan Bukan Alumni Pesantren (Studi pada kantor depag kabupaten Bangkalan). Jurnal Ekonomi MODERNISASI Fakultas ekonomi Universitas Kanjuruhan Malang.

Kasmir. (2018). Manajemen Sumber Daya Manusia. Depok: Rajawali Pers. 
Mulyani. (2012). Profesionalisasi Guru dan Implementasi KTSP. Cet. Jakarta: Gaung Persada Press

Musfiqon. (2012). Pengembangan Media Belajar dan Sumber Belajar. Jakarta: Prestasi Pustakakarya.

Nanang. (2016). Strategi Pendidikan [Educational Strategy]. Jakarta: Raja Graffindo Persada.

Novita. (2017). Pengaruh Kepemimpinan Dan Kompensasi Terhadap Kinerja Karyawan (Studi Kasus Pekerja Proyek Pada PT. ARILIUM). JIMF (Jurnal IImiah Manajemen Forkamma). ISSN (print): 2598-9545 \& ISSN (online): 2599-171X. Vol. 1, No. 3, Mei 2018.

Nuraini, T. (2013). Manajemen Sumber Daya Manusia. Yayasan Aini Syam: Pekanbaru.

Rohma, S., Harapan, E., \& Wardiah, D. (2020). The Influence of School-Based Management and Teacher's Professionalism toward Teacher's Performance. Journal of Social Work and Science Education, 1(1), 13-23.

Retrieved from https://ejournal.karinosseff.org/index.php/jswse/article/view/6

Septiani, V., \& Cahyono, D. (2019). Eduaction and Training Strategy in Palembang Aviation College. International Journal of Recent Technology and Engineering, 8 (3).

Sholeh, A. M., Tobari., Kesumawati, N. (2019). Development of The Practical Manual as A Learning Media for Simulator Aircraft Rescue and Fire Fifhting. International Journal of Scientific \& Technology Researsch 8 (10).

Sugiyono. (2016). Metode Penelitian Pendidikan: Pendekatan Kuantitatif, Kualitatif, dan R\&D. Bandung Alfabeta.

Suharsaputra. (2018). Supervisi Pendidikan. Bandung: PT refika Aditama.

Tobari., Kristiawan, M. \& Asvio, N. (2018). The Strategy of Headmaster on Upgrading Educational Quality in Asean Economic Community (AEC) Era. International Journal of Scientific \& Technology Research 7 (4).

Usman, H. (2008). Manajemen: Teori Praktik \& Riset Pendidikan. Jakarta: Bumi Aksara. 